\title{
Article \\ Effect of the Particle Size on TDA Shear Strength Parameters in Triaxial Tests
}

\author{
Hany El Naggar * and Khaled Zahran
}

check for updates

Citation: El Naggar, H.; Zahran, K. Effect of the Particle Size on TDA Shear Strength Parameters in Triaxial Tests. Buildings 2021, 11, 76. https://doi.org/10.3390/ buildings 11020076

Academic Editor: Łukasz Sadowski

Received: 12 January 2021

Accepted: 19 February 2021

Published: 23 February 2021

Publisher's Note: MDPI stays neutral with regard to jurisdictional claims in published maps and institutional affiliations.

Copyright: (c) 2021 by the authors. Licensee MDPI, Basel, Switzerland. This article is an open access article distributed under the terms and conditions of the Creative Commons Attribution (CC BY) license (https:/ / creativecommons.org/licenses/by/ $4.0 /)$.
Department of Civil \& Resource Engineering, Faculty of Engineering, Dalhousie University, Halifax, NS B3H 4R2, Canada; kh213504@dal.ca

* Correspondence: hany.elnaggar@dal.ca

\begin{abstract}
Tire recycling and reuse in North America and worldwide have increased considerably, intending to reduce the harmful effects of scrap tires on the environment. Accordingly, the use of tire derived aggregates (TDA) as backfill material in civil engineering applications is on the rise at an unprecedented rate. However, to use TDA in the construction industry, its strength and stiffness parameters properties must be evaluated. One key factor that is known to influence the strength and stiffness of backfill material is the particle size of the used material. Hence, in this paper, a series of large-scale triaxial tests on five TDA samples with different maximum particle size, $\mathrm{D}_{\max }$, of 19.05, 25.4, 38.1, 50.8 and $76.2 \mathrm{~mm}$ were conducted to investigate the effect of the particle size on the obtained results. The tests were done under consolidated drained conditions using three confining pressures of 50,100, and $200 \mathrm{kPa}$. The results showed that the shear strength of TDA increase by increasing the maximum particle size while the cohesion did not show a specific trend. Moreover, the samples exhibited an increase in the secant elastic modulus by increasing the particle size.
\end{abstract}

Keywords: tire derived aggregates (TDA); large-scale triaxial tests; particle size; shear strength; stiffness

\section{Introduction}

Tire-derived aggregate (TDA) is a relatively new construction material. It has gained acceptance over the last few decades as a backfill material for embankments and earthretaining structures due to its lightweight and outstanding geotechnical properties [1-17]. TDA has also been used around buried pipes to improve their performance [18-20] and underneath shallow foundations [21]. For example, Mahgoub and El Naggar [18,19] found that using TDA above buried pipes can reduce the pipes' stresses by 40 to $60 \%$. Likewise, using an underlying layer of TDA for shallow foundations results in a substantial improvement in transferring the stresses and reducing the stress influence zone beneath the foundation [21]. TDA was also used in dynamics and vibration control applications (e.g., [22-25]). For instance, Moussa and El Naggar [25] found that TDA-infilled buried trenches could substantially improve the buried infilled trenches' effectiveness to mitigate ground-borne vibrations. Geotechnical characterization is one of the main characteristics essential for adopting the TDA in the construction industry. However, TDA particles are considered relatively large compared to the standard testing equipment available. Therefore, practitioners are forced to test smaller TDA particle sizes that are not representative of the actual TDA sizes used in actual civil applications. Hence, the main focus of this work is studying the effect of the particle size on the shear strength and stiffness parameters of TDA using large-scale triaxial apparatus.

One of the earliest studies for the particle size effect was done by Kirkpatric [26] to study the particle size effect on the shear strength parameters of sand and glass beads. Five sand samples were tested, having increasing maximum particle size ranging between $0.39 \mathrm{~mm}$ and $2 \mathrm{~mm}$. Besides, three glass beads samples with maximum particle sizes ranging between $0.3 \mathrm{~mm}$ and $0.58 \mathrm{~mm}$ were also tested. This study showed that for the sand samples, the shear resistance slightly decreased with increasing the particle size. 
However, the glass beads samples showed an increasing shear resistance with increasing particle size. Likewise, Islam et al. [27] investigated the effect of particle size on the shear strength parameters of sands. Eight samples were tested, having uniform particle sizes ranging between $0.075 \mathrm{~mm}$ and $2.76 \mathrm{~mm}$. Two samples with graded particle sizes $(0.075$ to $1.18 \mathrm{~mm}$ and 0.075 to $2.36 \mathrm{~mm}$ ) were also tested. The tests were performed in a circular shear box with a diameter of $50.8 \mathrm{~mm}$ under a constant shearing rate. The results showed that the angle of internal friction increased from $35.54^{\circ}$ up to $42.24^{\circ}$ for the samples with uniform particle sizes. For the two samples with graded particle sizes, the internal friction angle increased from $41.18^{\circ}$ to $41.83^{\circ}$. Kim et al. [28] investigated the shear strength parameters of 3 coarse-grained soil samples having increasing maximum particle sizes; $4.75 \mathrm{~mm}, 7.9 \mathrm{~mm}$ and $15.9 \mathrm{~mm}$. The samples were tested in a large scale $300 \mathrm{~mm}$ square shear box. The tests were performed under three applied normal pressures of 98, 196 and $294 \mathrm{kPa}$ using a constant shear rate of $1 \mathrm{~mm} / \mathrm{min}$. The results showed that the angle of internal friction increased from $40.6^{\circ}$ for the $4.75 \mathrm{~mm}$ sample up to $54^{\circ}$ for the $15.9 \mathrm{~mm}$ sample. In the same year, Wang et al. [29] studied the particle size effect on the shear strength of accumulation soil. In this study, ten accumulated soil samples were tested, five in a $500 \mathrm{~mm}$ square direct shear box and the other five in a triaxial testing machine having a $100 \mathrm{~mm}$ cell diameter and $200 \mathrm{~mm}$ height. The samples had an increasing average particle size $\left(D_{50}\right)$ with a fixed maximum particle size $\left(D_{\max }\right)$. The shearing rate used in the study was $0.1 \mathrm{~mm} / \mathrm{min}$ at four confining pressures 100, 150, 200 and $250 \mathrm{kPa}$. Generally, the results showed that the shear resistance increased with increasing the average particle size of the sample being tested as the results from the direct shear tests indicated that the range of the angle of internal friction of the accumulation soil was 33.5 to $54.6^{\circ}$, while that reported from the triaxial tests indicate was 37.2 to $50.7^{\circ}$. Moreover, Vangla and Latha [30] investigated the particle size effect on three sand samples. The tested samples were fine, medium and coarse sand samples. The maximum particle size for the tested samples ranged between $0.425 \mathrm{~mm}$ and $4.75 \mathrm{~mm}$. The tests were conducted using a large-scale direct shear test with a $300 \mathrm{~mm}$ square shear box under three normal stresses of $21 \mathrm{kPa}, 37 \mathrm{kPa}, 58 \mathrm{kPa}$. The results showed that the friction angle increased from $35.9^{\circ}$ for the fine sand to $38.9^{\circ}$ for the coarse sand. As seen above, limited studies on the impact of particle size on the shear strength parameters of different soils have been performed using triaxial tests. Besides, available TDA triaxial testing data obtained with large-scale machines is limited and not comprehensive. In addition, according to the authors' knowledge, no research was done to study the particle size effect on the shear strength and stiffness parameters of TDA. Consequently, this paper investigates the effect of the TDA particle size on the shear strength and stiffness parameters using large-scale triaxial apparatus.

\section{Materials and Methods}

The TDA samples tested in this research were shredded at Halifax C\&D Recycling Ltd., Halifax, Nova Scotia, Canada, using the conventional tires shredding method by passing scrap tires through shredders in successive shredding cycles until reaching the targeted particle size range (Figure 1). In this study, five TDA samples with different maximum particle sizes, $\mathrm{D}_{\max }$, of $19.05,25.4,38.1,50.8$ and $76.2 \mathrm{~mm}$, were tested. The used TDA samples are classified as Type A-TDA as per ASTM D6270-08 [31] with an average aspect ratio of approximately 2 , defined as the ratio between the length to the width of the particle.

Any protruding steel wires from the TDA particles were removed entirely to protect the triaxial membrane from puncturing. So, the shear strength parameters, especially the cohesion resulting from these samples, are expected to be slightly conservative compared to the actual TDA used in civil engineering applications. The samples were sieved following the ASTM C136/C136M-14 procedures [32]. In this study, the TDA samples were having a particle size range between $9.5 \mathrm{~mm}$ up to the maximum particle size $\left(D_{\max }\right)$ existing in each sample, as shown in the gradation curves in Figure 2. Besides, the samples were 
named according to their maximum particle sizes $\left(D_{\max }\right)$. The compacted unit weight of the tested samples was $6.6 \pm 0.3 \mathrm{kN} / \mathrm{m}^{3}$.
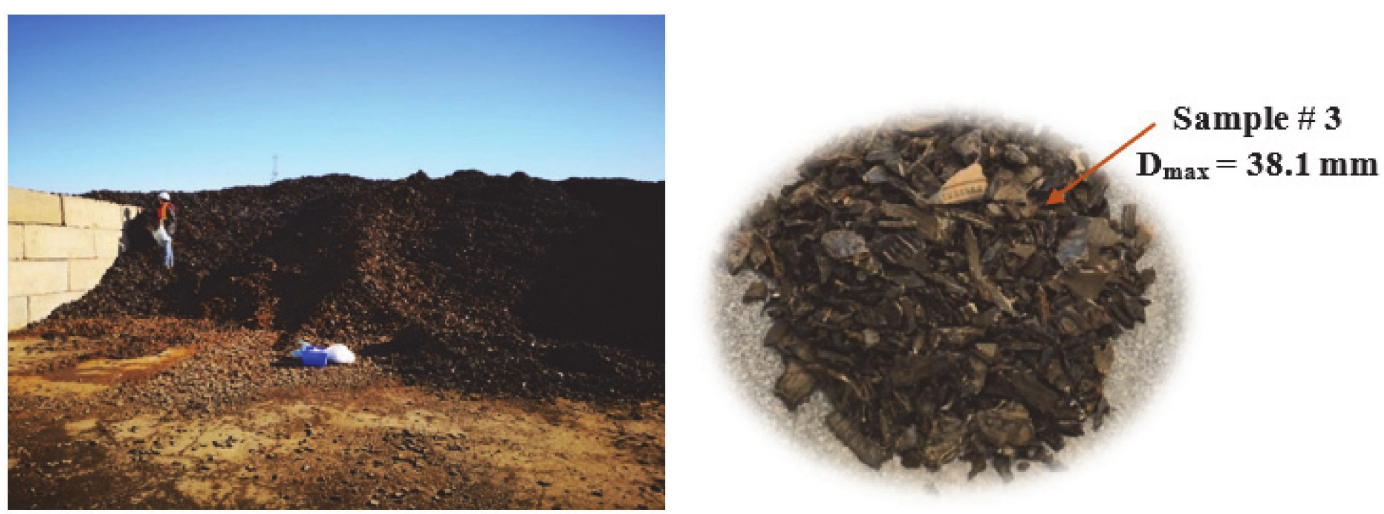

Figure 1. TDA from Halifax C\&D Recycling Ltd.

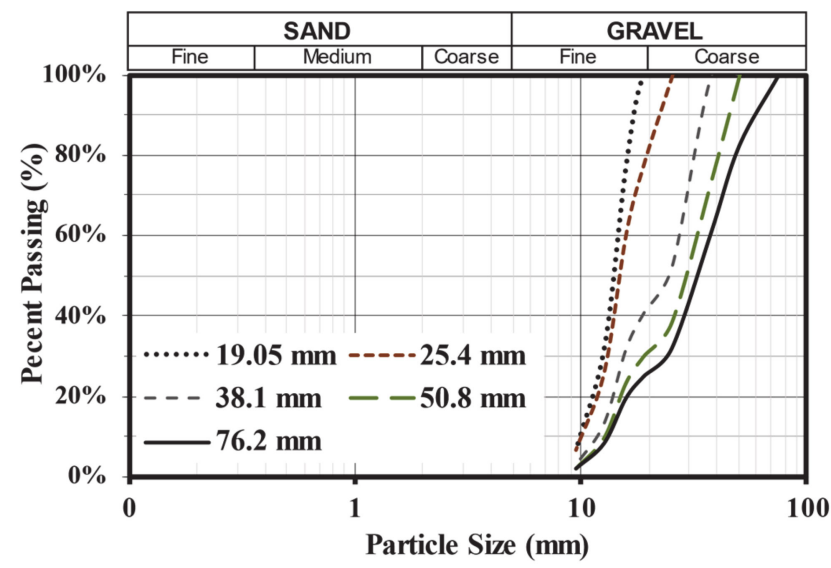

Figure 2. Gradation curves for the five samples.

The properties of the five samples are summarized in Table 1. The coefficient of uniformity increases as the maximum particle size increases, which means that the sample with larger particle sizes covers more particle size range than the samples with smaller particle sizes.

Table 1. Characteristics of the TDA used in the research.

\begin{tabular}{cccccc}
\hline Characteristics & Sample\#1 & Sample \#2 & Sample \#3 & Sample \#4 & Sample \#5 \\
\hline $\mathbf{D}_{\mathbf{1 0}}(\mathbf{m m})$ & 9.8 & 10 & 12 & 13.1 & 13.2 \\
\hline $\mathbf{D}_{\mathbf{3 0}}(\mathbf{m m})$ & 12.4 & 13.2 & 16 & 19 & 25 \\
\hline $\mathbf{D}_{\mathbf{5 0}}(\mathbf{m m})$ & 14 & 16 & 25 & 29.5 & 33 \\
\hline $\mathbf{D}_{\mathbf{6 0}}(\mathbf{m m})$ & 15.5 & 17 & 27.5 & 33 & 39 \\
\hline $\mathbf{D}_{\mathbf{m a x}}(\mathbf{m m})$ & 19.05 & 25.4 & 38.1 & 50.8 & 76.2 \\
\hline Size Range $(\mathbf{m m})$ & $9.5-19.05$ & $9.5-25.4$ & $9.5-38.1$ & $9.5-50.8$ & $9.5-76.2$ \\
\hline $\mathbf{C}_{\mathbf{u}}$ & 1.58 & 1.70 & 2.29 & 2.52 & 2.95 \\
\hline $\mathbf{C}_{\mathbf{c}}$ & 1.01 & 1.02 & 0.78 & 0.84 & 1.21 \\
\hline \multirow{2}{*}{ USCS Classification } & $\begin{array}{l}\text { Poorly } \\
\text { graded }\end{array}$ & $\begin{array}{l}\text { Poorly } \\
\text { graded }\end{array}$ & $\begin{array}{c}\text { Poorly } \\
\text { graded }\end{array}$ & $\begin{array}{c}\text { Poorly } \\
\text { graded }\end{array}$ & $\begin{array}{c}\text { Poorly } \\
\text { graded }\end{array}$ \\
\hline
\end{tabular}


The coefficients of uniformity and curvature were calculated as per Holtz and Kovacs [33] as following, respectively:

$$
\begin{gathered}
\mathrm{C}_{\mathrm{u}}=\mathrm{D}_{60} / \mathrm{D}_{10} \\
\mathrm{C}_{\mathrm{c}}=\mathrm{D}^{2}{ }_{30} /\left(\mathrm{D}_{10} \times \mathrm{D}_{60}\right)
\end{gathered}
$$

\section{Large-Scale Triaxial Apparatus}

In total, 18 consolidated drained large-scale triaxial tests were performed to assess the effect of the particle size on the shear strength and stiffness parameters of TDA. The samples were tested using a large-scale triaxial cell $152 \mathrm{~mm}$ (6 inches) in diameter by $320 \mathrm{~mm}$ in height, which is around 2.1 times the sample diameter and is in the range suggested by ASTM D7181-11 [34]. The axial loading was applied using the Instron 8501 hydraulic load frame (Norwood, MA, USA). A $1 \mathrm{~mm} / \mathrm{min}$ shearing rate was used in this study calculated in compliance with ASTM D7181-11 to allow the dissipation of any excess pore water pressure. An external load cell was used to record the axial load. Moreover, a linear variable displacement transducer (LVDT) was used to record the axial displacement. Two GDS Advanced Pressure-Volume Controllers (ADVDPC) were used to record the volume change of the sample and control the pressure during the shearing phase. The two pressure-volume controllers were kept at the same height and calibrated before each test to minimize the errors. Figure 3 shows the triaxial apparatus used in this research.

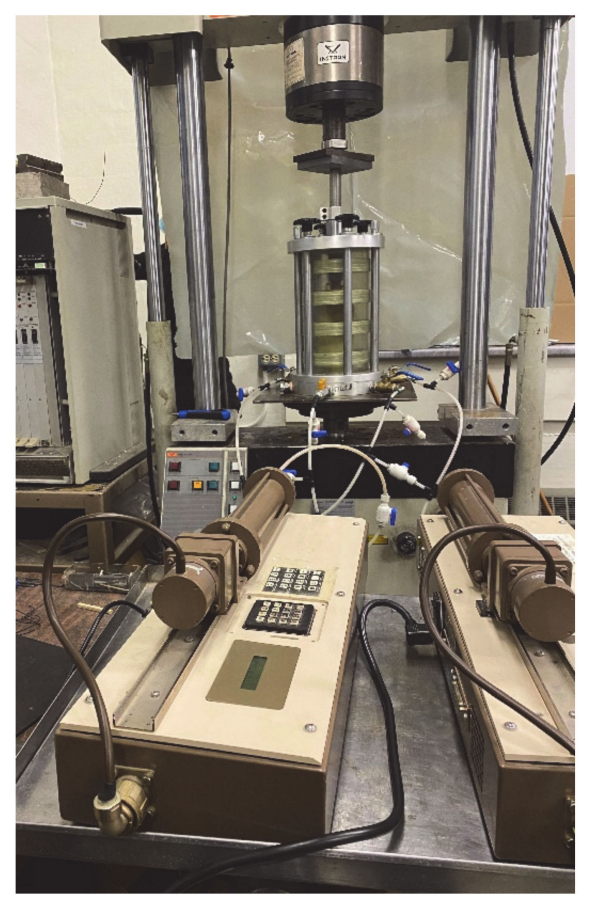

Figure 3. The Triaxial testing setup.

The height of the shaft used in the triaxial apparatus was increased to accommodate the excessive consolidation that occurs to the TDA samples due to the presence of large voids between the TDA particles and also to allow reaching the targeted 20\% strain level. The connection between the piston and specimen cap was a rigid connection so that the titling in the specimen cap will be minimal, as recommended by ASTM D7181-11. Choosing a rigid connection between the shaft and the specimen cap is recommended when testing a highly elastic material as TDA because TDA particles have very random shapes that will be too tough to level the surface of the sample without cap tilting. This kind of connection was modified after Baldi et al. [35] by permission from ASTM International, and it was verified by some researchers as Lade [36]. 


\section{Testing Scheme}

This section may be divided by subheadings. It should provide a concise and precise description of the experimental results, their interpretation, as well as the experimental conclusions that can be drawn.

\subsection{Sample Preparation Stage}

The TDA samples were checked for any protruding steel wires to avoid the puncture of the triaxial membrane. The specimens were compacted using a modified proctor hammer. Extensive care was given to the membrane during compaction to avoid membrane puncturing, and the compaction was done on five layers. According to ASTM D6270-08, compaction energy higher than $60 \%$ of the standard proctor will not affect the compacted unit weight of TDA significantly. So, compaction energy equal to, or slightly higher than, $60 \%$ of the standard proctor was applied to each sample. Researchers found that oven-dried TDA has different physical properties, and adding water to the sample will not affect the compacted unit weight. So, compaction was done on air-dried samples $[1,8,25,37]$.

The sample preparation was done in the following steps. First, the split mould was secured around the bottom and the top using hose clamps and a relatively thick Humboldt membrane was stretched around the split mould. Then, a vacuum was applied between the membrane and the compaction mould so the membrane will be stretched. After that, the sample was divided into five portions and each portion was weighed and added to the mould so that the compaction will be applied on five layers till reaching the targeted compacted unit weight. Next, the surface was levelled, and a porous stone was added to the top of the sample and the sample was inverted and centred over the base of the triaxial covering the two water inlets. The specimen cap and a porous stone were added to the top surface of the sample after levelling it as possible. In order to ensure the isolation between the cell pressure and the backpressure, two hose clamps were tightly secured around the specimen cap and the triaxial bottom plate. After that, the sample height and diameter were measured three times to calculate the initial volume of the specimen. Then, the shaft was connected to the specimen cap with grease on it to minimize the friction, and the cylindrical triaxial cell was assembled and placed in the center of the load frame. Finally, the loading frame was lowered to be barely touching the sample so that the uplift force, during saturation, will not push the shaft upward.

\subsection{Saturation Stage}

The triaxial was filled up with water at a low pressure of $10 \mathrm{kPa}$, to circulate the water through the entire triaxial cell and the two pressure-volume controllers while the drainage was kept open so large air bubbles will stream out of the system. This flushing procedure minimized the errors that may occur due to the compression of the air bubbles. At that point, back pressure is applied to the sample, so the air voids inside the sample are loaded up with water and entrapped air will be removed from the entire system.

The saturation process is a function of time and pressure. However, due to the high permeability and drainage coefficient of TDA, the saturation phase is relatively simple and fast compared to natural soils. The Skempton's pore water pressure parameter (B) was used to measure the degree of the sample saturation, and all the samples were saturated until reaching a minimum (B) value of 0.98 .

\subsection{Consolidation Stage}

The consolidation stage is achieved by increasing the confining pressure while keeping the pore pressure of the sample constant, and it is also considered to be relatively fast. Three confining pressures were used in the research: 50, 100 and $200 \mathrm{kPa}$. The volume of water driven out of the sample during the consolidation stage was measured using a plastic graduated measuring cylinder, and it was observed that a significant contraction occurred to the samples during the consolidation stage, so the height of the shaft had to be increased to reach the desirable strain level. 


\subsection{Shearing Stage}

To measure the shearing rate, the volumetric change was plotted against the logarithm of the time elapsed. However, the high permeability of TDA resulted in a shearing rate higher than the rate that could be controlled by our volume pressure controllers. So, a lower rate of $1 \mathrm{~mm} / \mathrm{min}$ was used for all the samples.

In the initial tests, a 30\% strain level was achieved. However, the samples were subjected to a severe potential of membrane puncturing, so a $20 \%$ strain level was chosen for the tests, which is sufficient since the TDA is an elastic material with no peak in its stress-strain curve, and according to ASTM D7181-11, in the absence of maximum stress, the deviatoric stress at $15 \%$ should be considered as the maximum stress.

Usually, TDA experiences a linear bulging after $10 \%$ strain due to the tilting of the specimen cap. However, using a fixed connection between the specimen cap and the shaft resulted in a right circular cylinder deformation as shown in Figure 4.

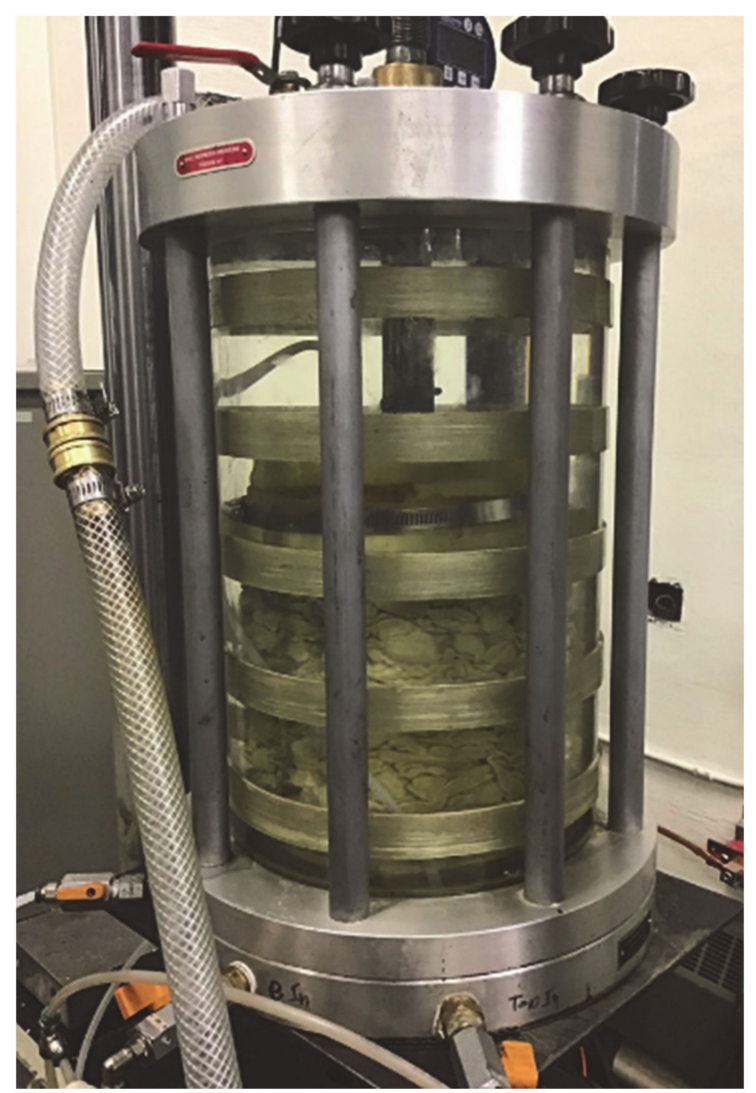

Figure 4. The sample deformation at 20\% Strain.

\subsection{Corrections}

Triaxial tests have several sources of errors that need to be corrected for in order to have more accurate results. Correction for the cross-sectional area during the consolidation and shearing phases is considered the primary source of errors in triaxial tests. Several researchers studied the cross-sectional area correction factor, were they recommended different correction equations to get the effective cross-sectional area as summarized in Table 2. 
Table 2. Cross-sectional area correction equations reported by different researchers.

\begin{tabular}{ccc}
\hline Study & Area Correction Equation & Deformation Shape \\
\hline La Rochelle et al. [38] & $A=A_{o}\left(1-\varepsilon_{v}\right) /\left(1-\varepsilon_{a}\right)$ & Right Circular Cylinder \\
\hline La Rochelle et al. [38] & $A=A_{o} \times\left[-0.25+\sqrt{\left(25-20 \varepsilon_{a}-5 \varepsilon_{a}^{2}\right)} / 4\left(1-\varepsilon_{a}\right)\right]^{2}$ & parabolic \\
\hline Garga and Zhang [39] & $d_{\max }=\frac{d_{c}}{4}\left[\left\{30 \frac{\left(1-\varepsilon_{v}\right)}{\left(1-\varepsilon_{a}\right)}\right\}-5\right]^{\frac{1}{2}}-1$ & parabolic \\
\hline
\end{tabular}

where: $\mathrm{A}=$ corrected area of the specimen, $\mathrm{A}_{\mathrm{o}}=$ initial area of the specimen, $\varepsilon_{\mathrm{v}}=$ volumetric strain of sample and $\varepsilon_{\mathrm{a}}=$ axial strain of sample.

However, in this research, an advanced MATLAB 2020b model was done to get an exponential equation for the volumetric change from which the effective cross-sectional area and the volumetric strain were calculated. These correction factors were applied to the results before evaluating the shear strength parameters.

\section{Results}

A total of 18 triaxial tests were conducted under consolidated drained conditions using three confining pressures; 50,100, $200 \mathrm{kPa}$ to resemble the stress levels expected in backfills, embankments and behind retaining walls. A total of five samples were tested, having an increasing maximum particle size $\left(D_{\max }\right)$ ranging between $19.05-76.2 \mathrm{~mm}$. All the samples had a diameter of $150 \mathrm{~mm}$ and a height of $320 \mathrm{~mm}$.

\subsection{Consistency and Repeatability of the Tests}

The random nature of TDA raises some doubts regarding the repeatability and accuracy of the driven tests. So, the $25.4 \mathrm{~mm}$ sample was duplicated under the three confining pressures to validate the repeatability and accuracy of the results. Figure 5 shows that the deviatoric stress-strain curves of the duplicated tests are in strong agreement, which proves the consistency and the accuracy of the results. The volumetric strain for the duplicated tests also showed an agreement between the results, as shown in Figure 6. The difference between the curves is minimal, which could be neglected and will not significantly affect the shear strength parameters.

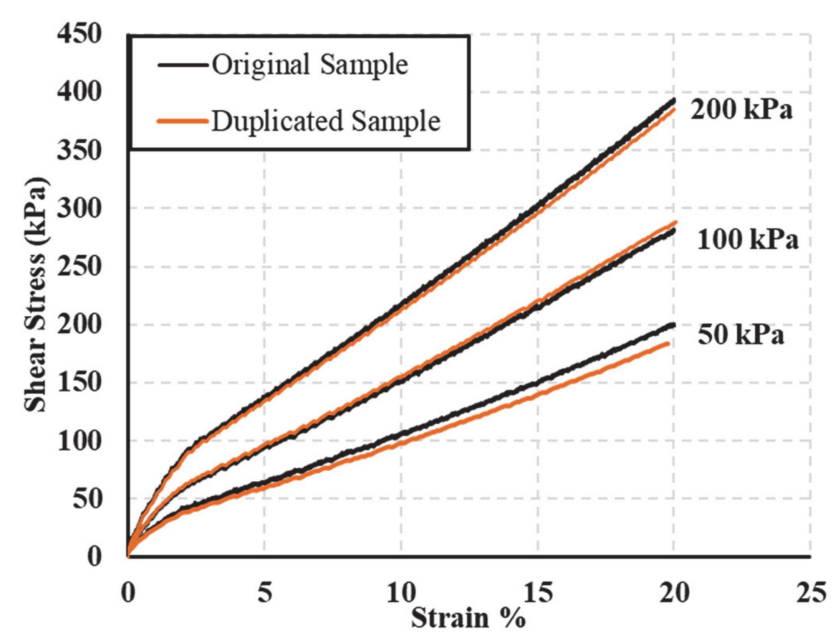

Figure 5. Deviatoric stress vs. strain curves for the duplicated tests for the $25.4 \mathrm{~mm}$ sample. 


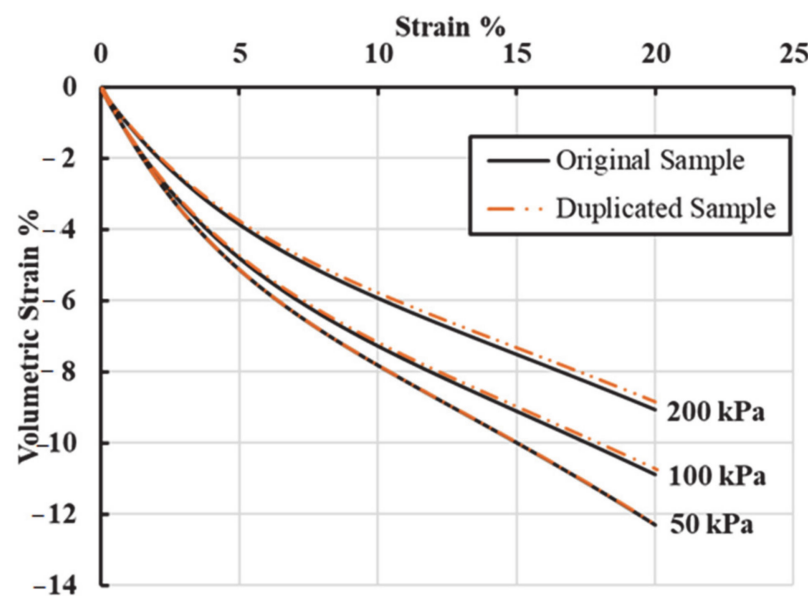

Figure 6. Volumetric strain vs. strain \% curves for the duplicated tests for the $25.4 \mathrm{~mm}$ sample.

\subsection{Stress-Strain Curves}

Figure 7 shows that all the samples exhibited a bilinear stress-strain behaviour with a close initial stiffness for the 19.05, 25.4 and $38.1 \mathrm{~mm}$ samples and a higher stiffness for the 50.8 and $76.2 \mathrm{~mm}$ samples. The samples undergo an initial steep increase in the deviatoric stress up to $2 \%$ strain, followed by a linearly increasing deviatoric stress up to $20 \%$ strain level. The deviatoric stress-strain curves of this study are in agreement with the previous studies conducted by Masad et al. [40], Lee et al. [13], Youwai and Bergado [41], and Zornberg [42]. These researchers reported fairly linear deviatoric stress-strain curves. The slight difference in the results between this study and the previous studies may be attributed to: (1) The different maximum particle size used. (2) Different samples with different gradation curves. (3) Different TDA composition depending on the TDA source (4) Most importantly, the random nature of TDA. -

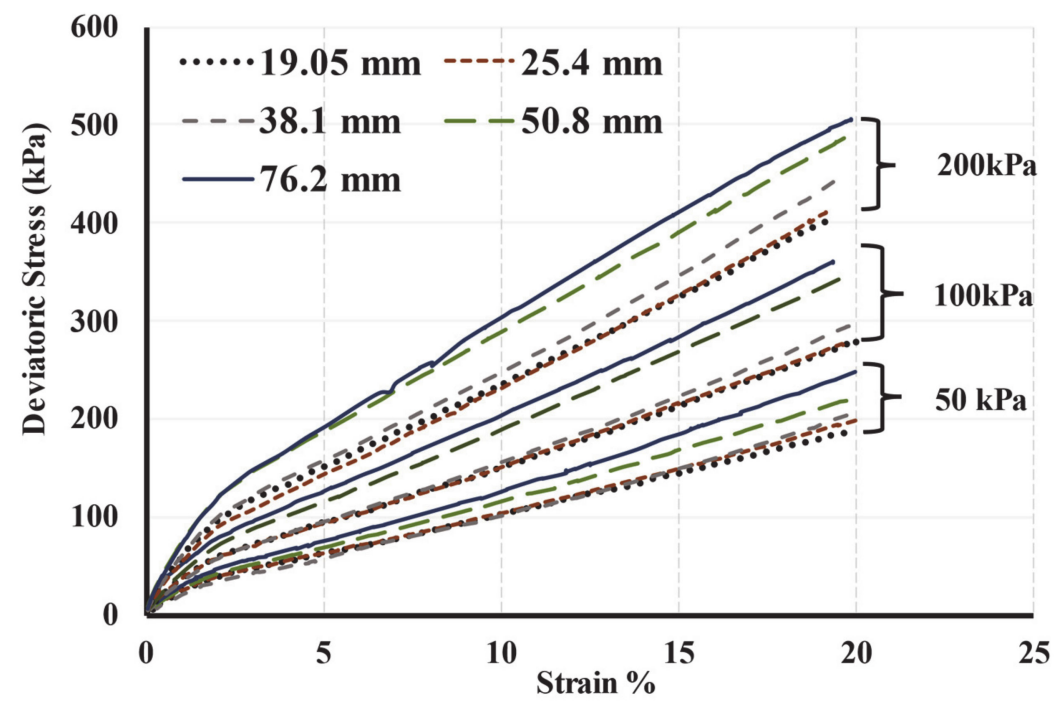

Figure 7. Deviatoric stress-strain curves for the five samples.

TDA samples do not reach a peak in their deviatoric stress-strain curves, and this phenomenon is clearly observed in Figure 7. However, ASTM D7181-11 recommended considering the deviatoric stress at $15 \%$ to be the maximum stress when no peak is observed in the stress-strain curve. Several practitioners used the deviatoric stress at $10 \%$ strain as the maximum stress for TDA to evaluate the shear strength parameters. In this study, shear strength parameters were calculated at both $10 \%$ and $15 \%$ strain levels. MohrCoulomb failure criterion was used in evaluating the shear strength parameters for the five 
tested samples. The angle of internal friction and cohesion were evaluated as using the following equation from Holtz and Kovacs [33].

$$
\tau=c^{\prime}+\sigma^{\prime} \tan \varphi^{\prime}
$$

where $\tau$ is the deviatoric stress at $10 \%$ and $15 \%$ strain levels, $c^{\prime}$ is the effective cohesion, which is the y-intercept, and $\varphi^{\prime}$ is the effective angle of internal friction.

Table 3 shows that the angle of internal friction increased by increasing the maximum particle size, $D_{\max }$. However, cohesion was almost constant within a range of $3.3 \mathrm{kPa}$ or less. Moreover, considering the deviatoric stress at $10 \%$ strain as the maximum stress results in more conservative shear strength parameters.

Table 3. The shear strength parameters for the five samples.

\begin{tabular}{|c|c|c|c|c|}
\hline \multirow[b]{2}{*}{ Sample $\left(D_{\max }\right)$} & \multicolumn{2}{|c|}{ Strain $10 \%$} & \multicolumn{2}{|c|}{ Strain $15 \%$} \\
\hline & $\begin{array}{c}\text { Angle of } \\
\text { Internal } \\
\text { Friction, } \varphi^{\prime}\left(^{\circ}\right)\end{array}$ & $\begin{array}{l}\text { Cohesion, } c^{\prime} \\
\quad(\mathbf{k P a})\end{array}$ & $\begin{array}{c}\text { Angle of } \\
\text { Internal } \\
\text { Friction, } \varphi^{\prime}\left(^{\circ}\right)\end{array}$ & $\begin{array}{c}\text { Cohesion, } c^{\prime} \\
\quad(\mathbf{k P a})\end{array}$ \\
\hline $19.05 \mathrm{~mm}$ & 17.8 & 21.6 & 21.3 & 30.5 \\
\hline $25.4 \mathrm{~mm}$ & 18.3 & 21.6 & 21.5 & 29.5 \\
\hline $38.1 \mathrm{~mm}$ & 18.6 & 19.4 & 22.3 & 28.7 \\
\hline $50.8 \mathrm{~mm}$ & 21.4 & 20.5 & 23.8 & 30.6 \\
\hline $76.2 \mathrm{~mm}$ & 21.8 & 23.4 & 25.6 & 32 \\
\hline
\end{tabular}

To simplify the understanding of the results, the results were plotted in columns, as shown below in Figure 8. The maximum difference in the angle of internal friction and cohesion between the samples is $4^{\circ}$ and $4 \mathrm{kPa}$, respectively, when considering the maximum stress to be at $10 \%$ strain. While the maximum difference becomes $4.3^{\circ}$ and $3.3 \mathrm{kPa}$, respectively, when considering the maximum stress to be at $15 \%$ strain. It can be noted that up to a maximum $\mathrm{D}_{50}$ of $38.1 \mathrm{~mm}$, the strength parameters were very close.

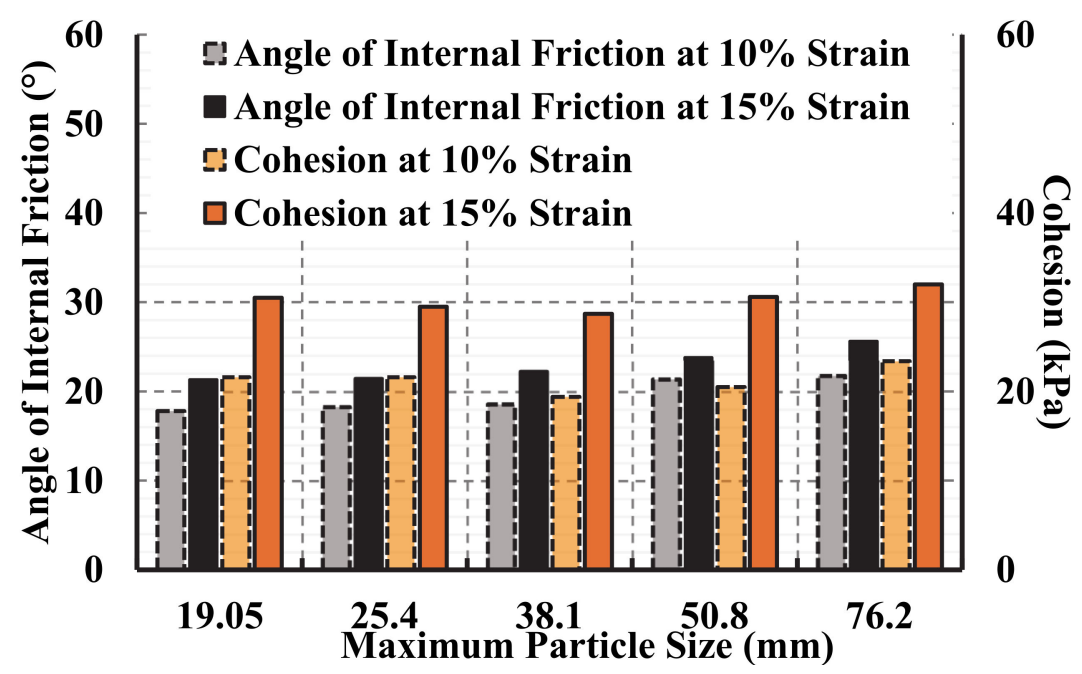

Figure 8. Angle of internal friction and cohesion for the five samples.

Figures 9 and 10 present the relations between the angle of internal friction and the cohesion, at $10 \%$ strain, with the uniformity coefficient, $\mathrm{C}_{\mathrm{u}}$, of the tested TDA samples and their maximum particle size, $D_{\max }$, respectively. It can be seen from the figures that the relationships between those parameters and friction angle are linear and increase as the $C_{u}$ and $D_{\max }$ increase. However, those parameters were found to have an insignificant effect on the cohesion. 


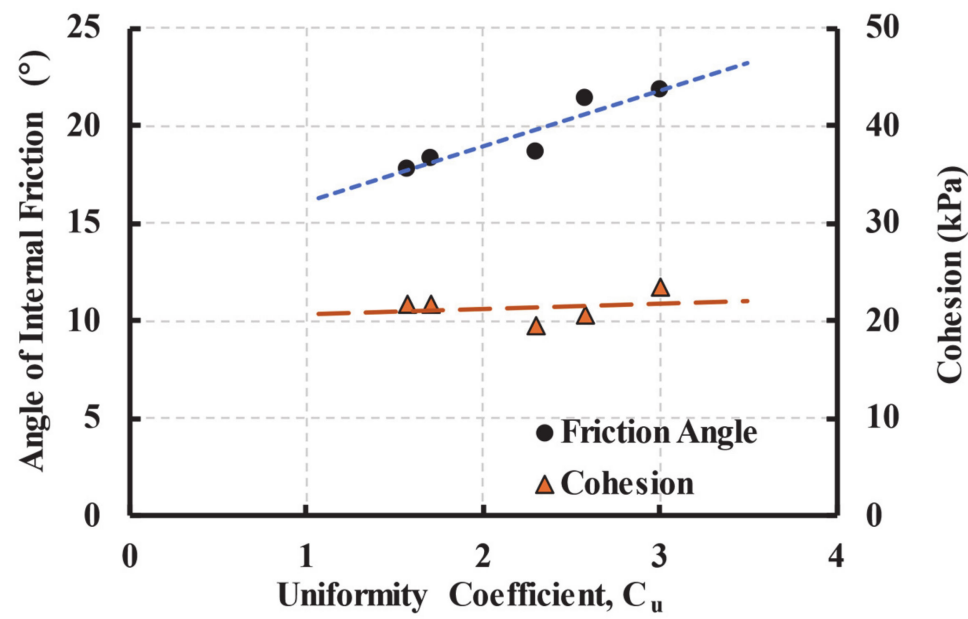

Figure 9. Angle of internal friction and cohesion for the five samples vs. their uniformity coefficient.

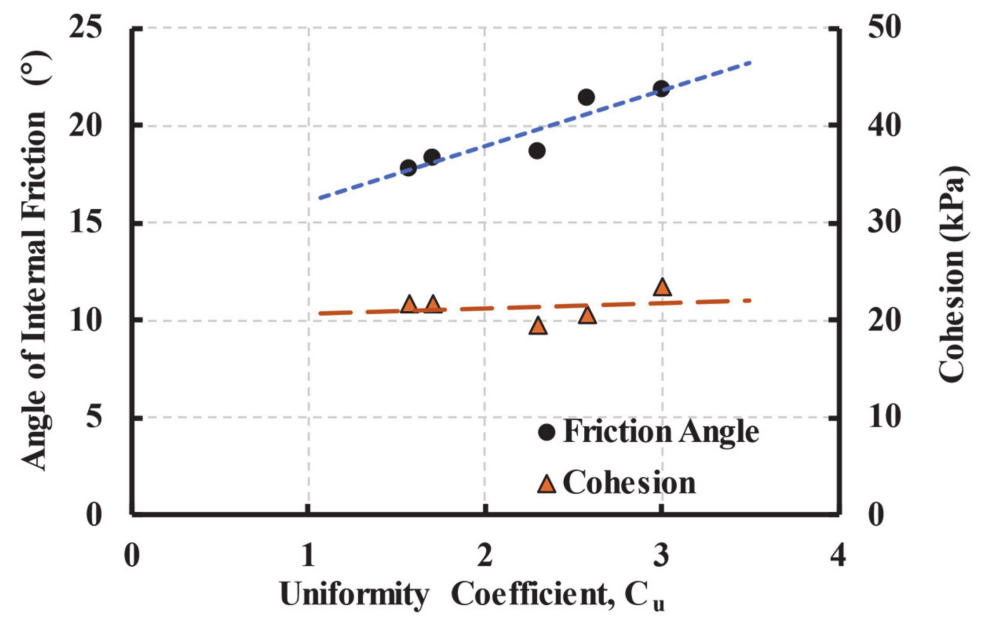

Figure 10. Angle of internal friction and cohesion for the five samples vs. their maximum particle sizes.

\subsection{Volumetric Strain}

The deformation that happens for saturated nature soils is mainly due to the expulsion of water from the samples voids, the reorientation of the soil particles and the deformation of the soil particles, which is almost negligible [43]. However, highly elastic material as TDA deforms for the following reasons: (1) Reorientation of the TDA particles, which is generally irrecoverable when unloaded; (2) Compression of the TDA particles, unlike conventional soils, and this is generally recoverable when unloaded. (3) Unlike conventional soils, bending of TDA particles contributes to the majority of the compression that happens to the TDA when loaded [44].

Figure 11a-c show the volumetric strain that occurred to the five samples under the three confining pressures. The samples showed a steep volumetric contraction followed by a steady decrease in the rate of volumetric change as the strain increases. The maximum particle size $\left(D_{\max }\right)$ did not show a correlation with the volumetric strain \% as under the $50 \mathrm{kPa}$ confining pressure, the volumetric strain \% decreased by increasing the maximum particle size. However, under the 100 and $200 \mathrm{kPa}$ confining pressures, there was no correlation between the maximum particle size and the confining pressures, as shown in the following figures. Overall trends in volumetric responses are very similar under the three confining pressures with a little decrease in the magnitude as the confining pressure increase. The confining pressure showed an inversely proportional correlation with the volumetric strain as the volumetric strain decreased when the confining pressure increased. The samples showed a volumetric strain \% between 10-12.5\% under the $50 \mathrm{kPa}$ confining pressure. However, this range decreased to be $9-10.8 \%$ under $100 \mathrm{kPa}$ confining pressure, 
and the range decreased more under the $200 \mathrm{kPa}$ to be $7.5-9.25 \%$. This behaviour could be attributed due to the presence of fewer voids within the samples when the confining pressure increases.
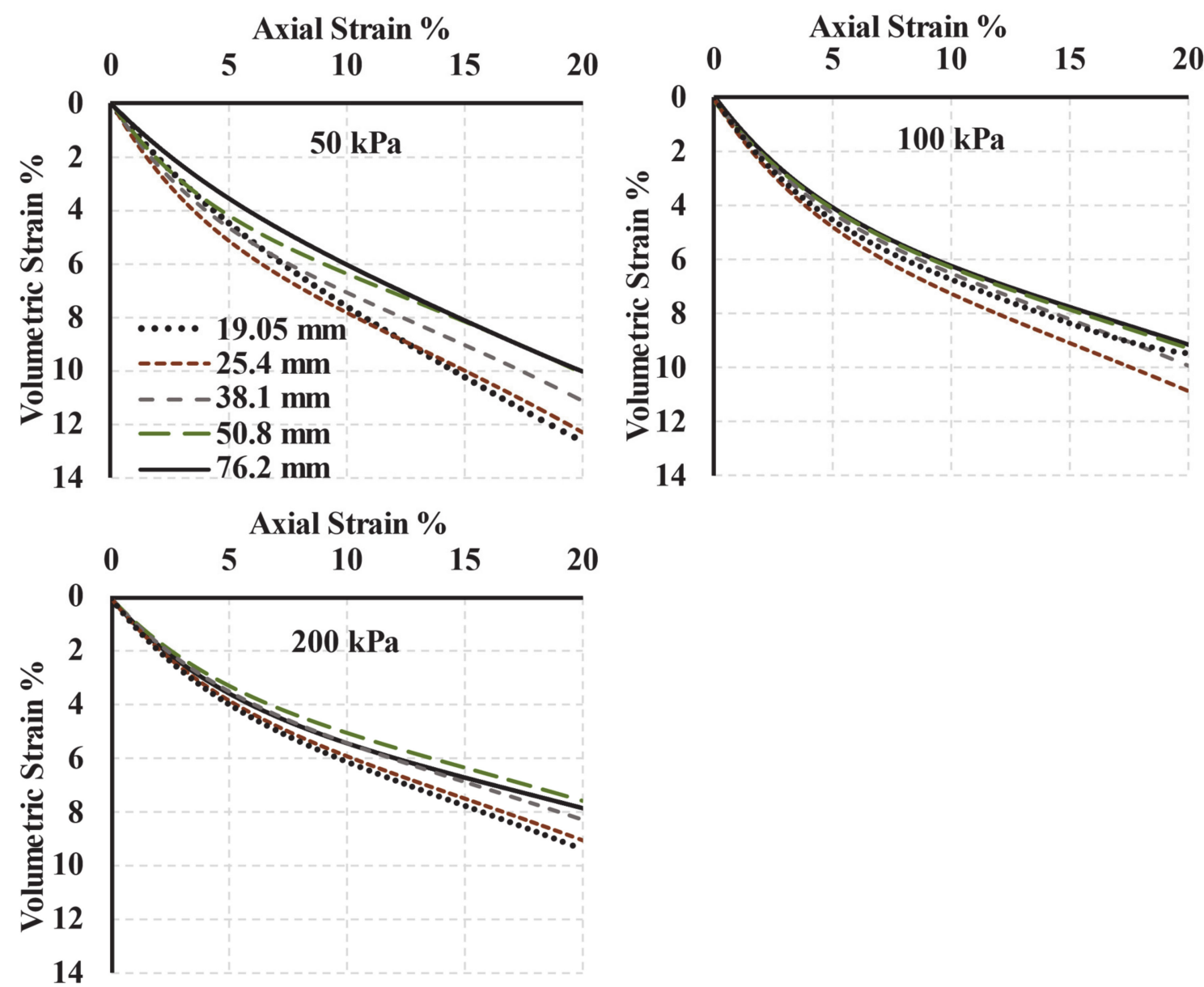

Figure 11. Volumetric strain \% for the samples under $50 \mathrm{kPa}, 100 \mathrm{kPa}$, and $200 \mathrm{kPa}$ confining pressures, respectively.

\subsection{Stiffness}

The particle size effect on the stiffness of the five samples was evaluated by calculating the secant elastic modulus, $E_{50}$, as reported in Figure 12. Generally, the elastic modulus reported in this study is in agreement with the elastic modulus of tire rubber reported by [6] that ranged between $730-2400 \mathrm{kPa}$. The secant elastic modulus was calculated using the following equation from Holtz and Kovacs [33]:

$$
E_{50}=\frac{\tau_{50}}{\varepsilon}
$$

where $\tau_{50}$ is half of the deviatoric stress at $10 \%$ and $\varepsilon$ is the corresponding axial strain. 


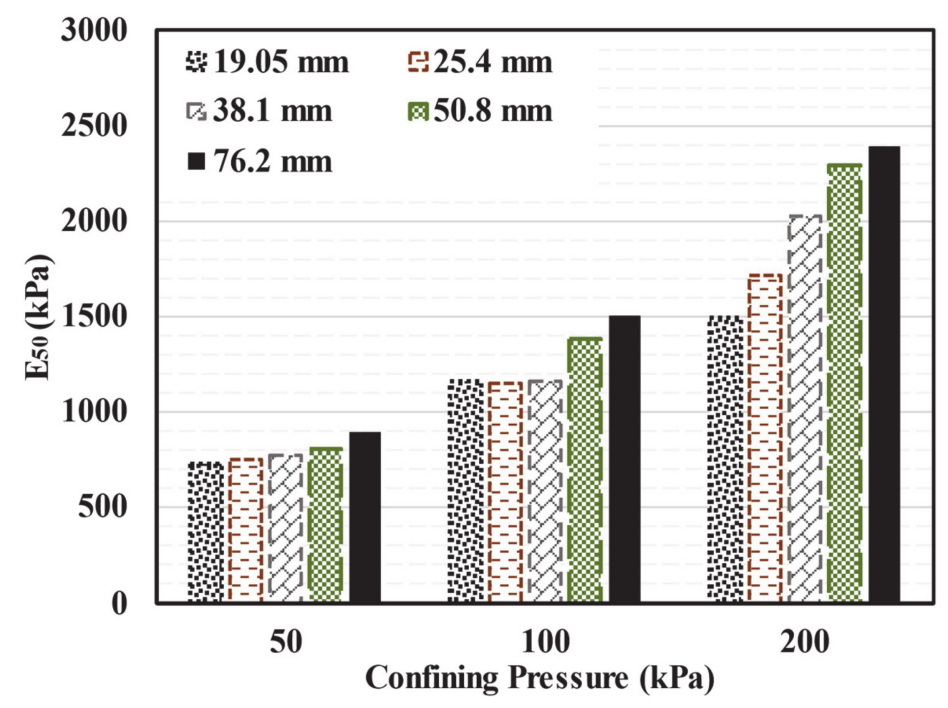

Figure 12. The secant elastic modulus at $10 \%$ strain.

Figure 12 shows that the secant elastic modulus increases when the particle size increases. In addition, the fact that the elastic modulus increases when the maximum particle size increases is attributed to the less freedom the particles with larger size have to reorient within the sample as the maximum particle size $\left(D_{\max }\right)$ is increasing while the triaxial cell diameter was kept constant. It could also be attributed to the presence of less steel wires in the smaller particles, unlike the large particles, which usually contain much higher steel wires content.

\subsection{Stiffness Degradation of TDA}

The stiffness behaviour of geomaterials under static loading could be classified according to strain levels [45]. As shown in Figure 7, at all strains, the overall stiffness of all specimens under the confining pressure of $200 \mathrm{kPa}$ is higher than those under $100 \mathrm{kPa}$. Likewise, the stiffness of all specimens under confining pressure of $100 \mathrm{kPa}$ is higher than those under $50 \mathrm{kPa}$. Figure 13 shows the stiffness degradation behaviour of TDA based on the strain levels under the three considered confining pressures. Atkinson and Sallfors [45] divided strain levels into three distinct groups, (i) very small strains, (ii) small strains, and (iii) large strains. Very small strains could only be induced by geophysical means, and the stress-strain relationships can not be reliably measured in the lab using mechanical means at this strain level. Hence, it is assumed that the stress-strain behaviour is linear elastic in the very small strain range [45]. For TDA, it can be seen from Figures 7 and 13 that upon reaching a strain level near $0.02 \%$, the stress-strain behaviour becomes noticeably nonlinear, and the secant modulus, $\mathrm{E}_{\mathrm{sec}}$, begins to degrade nonlinearly with the increasing strain. This strain zone is defined as the small strain zone and ends at a strain level of about $0.3 \%$. The onset of the large strain behaviour zone occurs at a strain level of about $0.3 \%$. Also, it can be noticed from Figure 13 that at a strain level of about $1 \%$, the secant modulus of TDA becomes relatively small and loses 50 to $80 \%$ of its threshold. Under confining pressures of 100 and $200 \mathrm{kPa}$, the TDA loses approximately $90 \%$ of its stiffness at a $5 \%$ strain. 

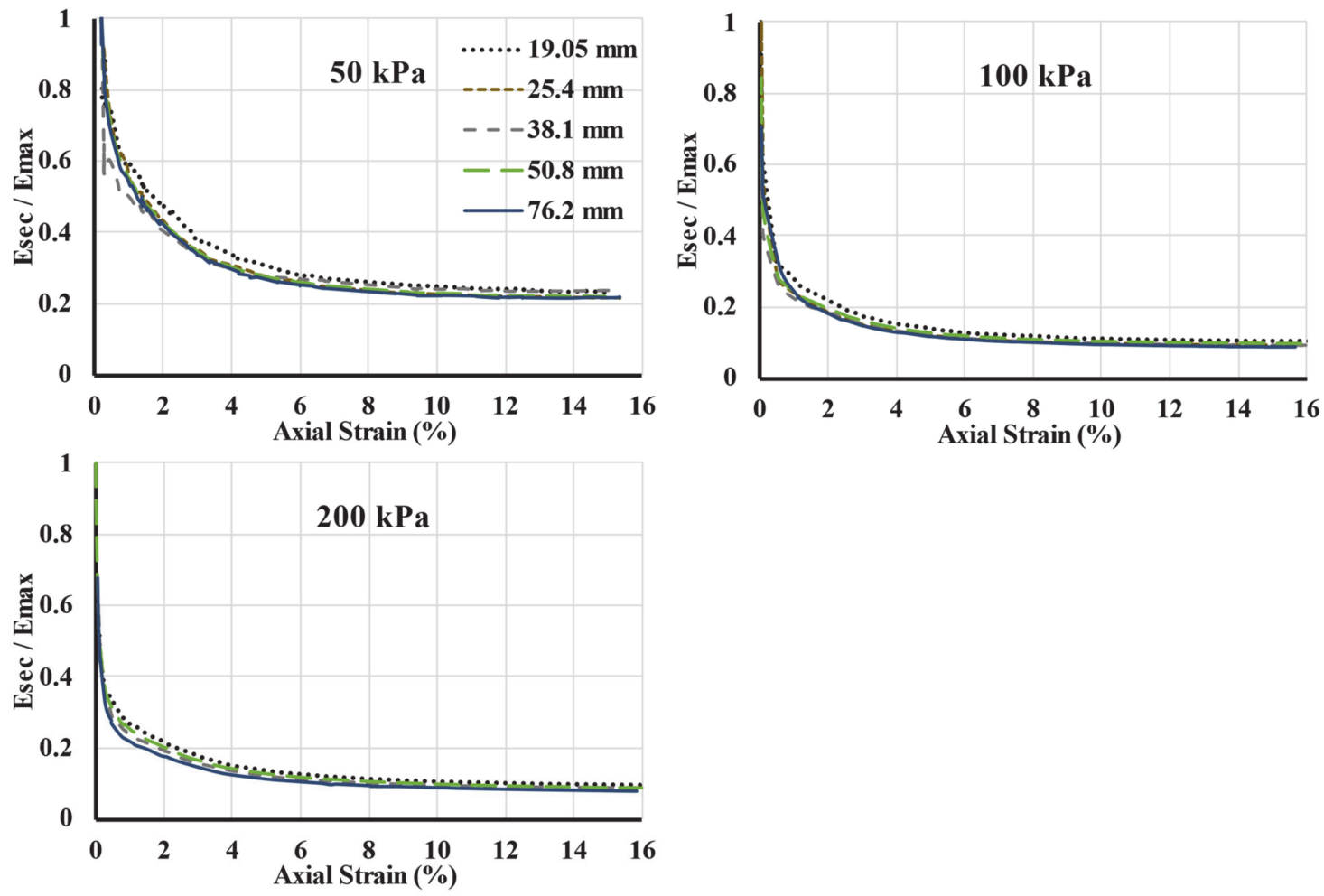

Figure 13. Stiffness degradation curves for TDA based on the strain levels.

\section{Conclusions}

To study the particle size effect on the TDA's shear strength and stiffness parameters, a series of large-scale triaxial tests were conducted on five different TDA samples with maximum particle size $\left(D_{\max }\right)$ ranging between $19.05-76.2 \mathrm{~mm}$. Based on the results of this study, it could be concluded that:

1. The effective angle of internal friction of TDA increases by increasing the maximum particle size.

2. The effective angle of internal friction was also found to increase as the coefficient of uniformity increases.

3. The cohesion of TDA did not show a defined correlation with the particle size as the cohesion exhibited a slight decrease followed by an increase by increasing the particle size. i.e., the interlocking cohesion of TDA is not significantly affected by the particle size (the difference was less than $3.3 \mathrm{kPa}$ at most). The same conclusion was reported by El Naggar et al. [6] from direct shear tests on TDA.

4. The secant elastic modulus of TDA increases by increasing the maximum particle size $\left(D_{\max }\right)$ or the confining pressure.

5. At all strains, the overall stiffness of all specimens increases as the confining pressure increase.

6. Upon reaching a strain level near $0.02 \%$, in the small strain zone, the stress-strain behaviour becomes noticeably nonlinear, and the secant modulus, $\mathrm{E}_{\mathrm{sec}}$, begins to degrade nonlinearly with the increasing strain up to a strain level of about $0.3 \%$.

7. The onset of the large strain behaviour zone occurs at a strain level of about $0.3 \%$. At a strain level of about 1\%, in the large strain zone, the secant modulus of TDA becomes relatively small and loses 50 to $80 \%$ of its threshold.

8. At higher strain levels, $5 \%$ and more, under confining pressures of 100 and $200 \mathrm{kPa}$, the TDA loses approximately $90 \%$ of its stiffness. 
Author Contributions: Conceptualization, H.E.N.; Data curation, K.Z.; Investigation, H.E.N.; Supervision, H.E.N.; Writing—original draft, H.E.N. and K.Z.; Writing—review \& editing, H.E.N. Both authors have read and agreed to the published version of the manuscript.

Funding: This research was funded by The Natural Sciences and Engineering Research Council of Canada (NSERC) and Divert NS (Grant No: RGPIN-2016-05428).

Institutional Review Board Statement: Not applicable.

Informed Consent Statement: Not applicable.

Data Availability Statement: Data is contained within the article.

Acknowledgments: The authors acknowledge the funding provided by the Natural Sciences and Engineering Research Council of Canada (NSERC) and Divert NS for this research project. They are also grateful for Halifax C \& D Recycling Ltd. (HCD) support and generosity for supporting this research.

Conflicts of Interest: The authors declare that they have no known competing financial interests or personal relationships that could have appeared to influence the work reported in this paper.

\section{References}

1. Ahmed, I.; Lovell, C. Rubber soils as lightweight geomaterial. Transp. Res. Board 1993, 1422, 61-70.

2. Ahn, I.S.; Cheng, L.; Fox, P.; Wright, J. Material properties of large-size tire derived aggregate for civil engineering applications. J. Mater. Civ. Eng. 2015, 27, 04014258. [CrossRef]

3. Bosscher, P.J.; Edil, T.B.; Kuraoka, S. Design of Highway Embankments Using Tire Chips. J. Geotech. Geoenvironmental Eng. 1997, 123, 295-304. [CrossRef]

4. Cecich, V.; Gonzales, L.; Hoisaeter, A.; Williams, J.; Reddy, K. Use of Shredded Tires as Lightweight Backfill Material for Retaining Structures. Waste Manag. Res. 1996, 14, 433-451. [CrossRef]

5. El Naggar, H.; Soleimani, P.; Fakhroo, A. Strength and Stiffness Properties of Green Lightweight Fill Mixtures. Geotech. Geol. Eng. 2016, 34, 867-876. [CrossRef]

6. El Naggar, H.; Zahran, K.; Moussa, A. Effect of the Particle Size on the TDA Shear Strength and Stiffness Parameters in Large-Scale Direct Shear Tests. Geotechnics 2021, 1, 1. [CrossRef]

7. El Naggar, H.; Ashari, M.; Mahgoub, A. Development of an Empirical Hyperbolic Material Model for TDA Using Large Scale Triaxial Testing. Int. J. Geotech. Eng. (Minor Revis.) 2021.

8. Humphrey, D.N.; Sandford, T.C.; Cribbs, M.M.; Manion, W.P. Shear strength and compressibility of tire chips for use as retaining wall backfill. Transp. Res. Rec. 1993, 1422, 29-35.

9. Humphrey, D.N.; Eaton, R.A. Field Performance of Tire Chips as Subgrade Insulation for Rural Roads. In Proceedings of the Transportation Research Board Conference Proceedings, Minneapolis, MN, USA, 25-29 June 1995.

10. Humphrey, D.N.; Manion, W.P. Properties of tire chips for lightweight fill. In Grouting, Soil Improvement and Geosynthetics; ASCE: Reston, VA, USA, 1992; pp. 1344-1355.

11. Humphrey, D.N.; Nickles, W.L. Tire chips as subgrade insulation and lightweight fill. In Proceedings of the 18th Annual Meeting of the Asphalt Recycling and Reclaiming Association, Annapolis, MD, USA, 1994; pp. 83-105.

12. Lee, H.J.; Roh, H.S. The use of recycled tire chips to minimize dynamic earth pressure during compaction of backfill. Constr. Build. Mater. 2007, 21, 1016-1026. [CrossRef]

13. Lee, J.H.; Salgado, R.; Bernal, A.; Lovell, C.W. Shredded Tires and Rubber-Sand as Lightweight Backfill. J. Geotech. Geoenvironmental Eng. 1999, 125, 132-141. [CrossRef]

14. Shahrokhi-Shahraki, R.; Kwon, P.S.; Park, J.; O'Kelly, B.C.; Rezania, S. BTEX and heavy metals removal using pulverized waste tires in engineered fill materials. Chemosphere 2020, 242, 125281. [CrossRef]

15. Sparkes, J.; El Naggar, H.; Valsangkar, A. Compressibility and Shear Strength Properties of Tire-Derived Aggregate Mixed with Lightweight Aggregate. J. Pipeline Syst. Eng. Pr. 2019, 10, 04018031. [CrossRef]

16. Soltani, A.; Taheri, A.; Deng, A.; O'Kelly, B.C. Improved Geotechnical Behavior of an Expansive Soil Amended with Tire-Derived Aggregates Having Different Gradations. Minerals 2020, 10, 923. [CrossRef]

17. Zahran, K.; El Naggar, H. Effect of Sample Size on TDA Shear Strength Parameters in Direct Shear Tests. Transp. Res. Rec. J. Transp. Res. Board 2020, 2674, 1110-1119. [CrossRef]

18. Mahgoub, A.; El Naggar, H. Using TDA as an Engineered Stress-Reduction Fill over Preexisting Buried Pipes. J. Pipeline Syst. Eng. Pr. 2019, 10, 04018034. [CrossRef]

19. Mahgoub, A.; El Naggar, H. Innovative Application of Tire-Derived Aggregate around Corrugated Steel Plate Culverts. J. Pipeline Syst. Eng. Pr. 2020, 11, 04020025. [CrossRef]

20. Mahgoub, A.; El Naggar, H. Coupled TDA-Geocell Stress-Bridging System for Buried Corrugated Metal Pipes. J. Geotech. Geoenvironmental Eng. 2020, 146, 04020052. [CrossRef] 
21. Mahgoub, A.; El Naggar, H. Using TDA Underneath Shallow Foundations: Field Tests and Numerical Modelling. J. Comput. Geotech. 2020. (In Production) [CrossRef]

22. Gabryś, K.; Sas, W.; Soból, E.; Głuchowski, A. Application of bender elements technique in testing of anthropogenic soil-Recycled concrete aggregate and its mixture with rubber chips. Appl. Sci. 2017, 7, 741. [CrossRef]

23. Sas, W.; Głuchowski, A.; Szymański, A. The geotechnical properties of recycled concrete aggregate with addition of rubber chips during cyclic loading. Int. J. GEOMATE 2017, 12, 25-32. [CrossRef]

24. Moussa, A.; El Naggar, H. Dynamic Characterization of Tire Derived Aggregates. J. Mater. Civ. Eng. 2021, 33, 04020471. [CrossRef]

25. Moussa, A.; El Naggar, H. Numerical Evaluation of Buried Wave Barriers Performance. Int. J. Geosynth. Ground Eng. 2020, 6, 1-13. [CrossRef]

26. Kirkpatric, W.M. Effects of Grain Size and Grading on the Shearing Behaviour of Granular Materials. In Proceedings of the 6th International Conference on Soil Mechanics and Foundation Engineering, Montreal, QC, Canada, 8-15 September 1965; Volume I, pp. 273-277.

27. Islam, M.N.; Siddika, A.; Hossain, M.B.; Rahman, A.; Asad, M.A. Effect of particle size on the shear strength behaviour of sands. Aust. Geomech. J. 2011, 46, 85-95.

28. Kim, D.; Ha, S. Effects of Particle Size on the Shear Behavior of Coarse Grained Soils Reinforced with Geogrid. Materials 2014, 7, 963-979. [CrossRef]

29. Wang, J.-J.; Zhang, H.-P.; Tang, S.-C.; Liang, Y. Effects of Particle Size Distribution on Shear Strength of Accumulation Soil. J. Geotech. Geoenvironmental Eng. 2013, 139, 1994-1997. [CrossRef]

30. Vangla, P.; Latha, G.M. Influence of Particle Size on the Friction and Interfacial Shear Strength of Sands of Similar Morphology. Int. J. Geosynth. Ground Eng. 2015, 1, 1-12. [CrossRef]

31. ASTM D6270-08. Standard Practice for Use of Scrap Tires in Civil Engineering Applications; ASTM International: West Conshohocken, PA, USA, 2012.

32. ASTM C136/C136M-14. Standard Test Method for Sieve Analysis of Fine and Coarse Aggregates; ASTM International: West Conshohocken, PA, USA, 2014.

33. Holtz, R.; Kovacs, W. An Introduction to Geotechnical Engineering; Prentice-Hall, Inc.: Upper Saddle River, NJ, USA, 1981; ISBN 0-13-484394-0.

34. ASTM D7181-11. Method for Consolidated Drained Triaxial Compression Test for Soils; ASTM International: West Conshohocken, PA, USA, 2011.

35. Baldi, G.; Hueckel, T.; Pellegrini, R. Thermal volume changes of the mineral-water system in low-porosity clay soils. Can. Geotech. J. 1988, 25, 807-825. [CrossRef]

36. Lade, P.V. Triaxial Testing of Soils; Wiley, Blackwell: New York, NY, USA, 2016.

37. Moo-Young, H.; Sellasie, K.; Zeroka, D.; Sabnis, G. Physical and Chemical Properties of Recycled Tire Shreds for Use in Construction. J. Environ. Eng. 2003, 129, 921-929. [CrossRef]

38. La Rochelle, P.; Leroueil, S.; Trak, B.; Blais-Leroux, L.; Tavenas, F. Observational approach to membrane and area corrections in triaxial tests. Adv. Triaxial Test. Soil Rock STP 1988, 977, 715-731.

39. Garga, V.K.; Zhang, H. Volume changes in undrained triaxial tests on sands. Can. Geotech. J. 1997, 34, 762-772. [CrossRef]

40. Chaney, R.; Demars, K.; Masad, E.; Taha, R.; Ho, C.; Papagiannakis, T. Engineering Properties of Tire/Soil Mixtures as a Lightweight Fill Material. Geotech. Test. J. 1996, 19, 297-304. [CrossRef]

41. Youwai, S.; Bergado, D.T. Strength and deformation characteristics of shredded rubber tire sand mixtures. Can. Geotech. J. 2003, 40, 254-264. [CrossRef]

42. Zornberg, J.G.; Cabral, A.R.; Viratjandr, C. Behaviour of tire shred sand mixtures. Can. Geotech. J. 2004, 41, 227-241. [CrossRef]

43. Yi, Y.; Meles, D.; Nassiri, S.; Bayat, A. On the compressibility of tire-derived aggregate: Comparison of results from laboratory and field tests. Can. Geotech. J. 2015, 52, 442-458. [CrossRef]

44. Meles, D.; Bayat, A.; Shafiee, M.H.; Nassiri, S.; Gül, M. Investigation of tire derived aggregate as a fill material for highway embankment. Int. J. Geotech. Eng. 2013, 8, 182-190. [CrossRef]

45. Atkinson, J.; Sallfors, G. Experimental determination of stress-strain-time characteristics in laboratory and in situ tests. In Proceedings of the 10th European Conference on Soil Mechanics and Foundation Engineering, Florence, Italy, 26-30 May 1991; Volume 3, pp. 915-956. 